\title{
Prevalence of plasmid-mediated resistance genes among multidrug-resistant uropathogens in Egypt
}

\author{
Ann A Elshamy, Khaled M Aboshanab, Mahmoud A Yassien, Nadia A Hassouna
}

Department of Microbiology \& Immunology, Faculty of Pharmacy, Ain Shams University, Cairo, Egypt.

\section{Emails:}

Email: Ann A Elshamy - ann.elshamy@pharm.asu.edu.eg; Mahmoud A Yassien - myassien61@yahoo.com; Nadia A Hassouna-nadia.hassouna46@gmail.com

\begin{abstract}
Background: The emergence of multidrug-resistant (MDR) uropathogens has become a public health threat and current knowledge of the genotypic basis of bacterial resistance is essential for selecting appropriate treatment options.

Objectives: To determine the prevalence of antimicrobial resistance among MDR uropathogens and to elucidate the molecular bases of plasmid-mediated resistance.

Methods: Bacterial isolates were recovered from urine specimens of 150 out-patients with signs and symptoms of urinary tract infections (UTIs) at El-Demerdash Hospital, Cairo, Egypt. Standard methods were used for identification, antimicrobial susceptibility testing was performed according to CLSI guidelines.

Results: Among the recovered isolates, $22.7 \%$ and $77.3 \%$ were Gram-positive, and negative, respectively. Of which; $43.3 \%$ were MDR with $60 \%$ harboring plasmids. Extended spectrum $\beta$-lactamase (ESBL) genes ${ }^{b l a}$ CTX-M, ${ }^{b l a}$ SHV, and ${ }^{b l d}$ TEM were detected on plasmids of $89.7 \%, 41 \%$, and $84.6 \%$ of the tested isolates, respectively. The aminoglycoside resistance gene aac6'-Ib/aac-6'-Ibor was found on plasmids of $92.3 \%$ of the tested isolates followed by qnrS $(92.3 \%)$, qnrB $(46.2 \%)$, and qnrA $(7.7 \%)$. The most prevalent quinolone efflux pump gene was oqxB (38.5\%), followed by oqxA (20.5\%), then qep $A(10.3 \%)$.

Conclusion: High levels of resistance to nitrofurans, $\beta$-lactam/ $\beta$-lactamase inhibitor, cephalosporins, aminoglycosides, and
\end{abstract} fluoroquinolones were detected, and their use as empirical treatment for UTIs has become questionable.

Keywords: ESBLs, qnR, plasmid-mediated, uropathgens, antibacterial resistance.

DOI: https://dx.doi.org/10.4314/ahs.v20i1.24

Cite as: Elshamy AA, Aboshanab KM, Yassien MA, Hassouna NA. Prevalence of plasmid-mediated resistance genes among multidrug-resistant uropathogens in Egypt Afri Health Sci. 2020;20(1):190-8. bttps:/ / dx.doi.org/10.4314 / abs.v20i1.24

\section{Introduction}

Urinary tract infection (UTI) is one of the most common infections worldwide which may be caused by Gram-negative or Gram-positive bacteria, as well as by some fungi. The most common causative organism is Escherichia E. coli. Antimicrobial resistance (AMR) has become a ma-

\section{Corresponding author:}

Khaled M Aboshanab,

Department of Microbiology and Immunology,

Faculty of Pharmacy, Ain shams University,

Organization of African Unity St.,

POB: 11566, Abbassia, Cairo, Egypt.

Tel: (202)28434595

Mobile: (002)01007582620

Fax: (202) 24051107

Email: aboshanab2012@pharma.asu.edu.eg jor threat to public health in many countries. There has been a steady increase in AMR to the agents commonly used in treatment of UTIs ${ }^{2,3}$. In most UTI cases, empirical therapy is initiated before the results of urine culture and sensitivity are available, thus it is necessary to have AMR surveillance ${ }^{4}$. The emergence and spread of multidrug-resistant (MDR) organisms, which show resistance to three or more classes of antimicrobials ${ }^{5}$, is increasing over time; and UTI cases requiring intravenous therapy due to the lack of effective oral treatment has become a challenge for physicians, complicating a previously simple-to-treat infection ${ }^{3}$.

Extended Spectrum Beta Lactamases (ESBLs) have emerged as a chief mechanism of resistance among uropathogens ${ }^{6}$. These ESBLs are enzymes that trigger the resistance against $\beta$-lactam antibiotics by hydrolysis of the 
$\beta$-lactam ring 7 . Regrettably, ESBL-producing organisms usually carry resistance determinants to other antimicrobial agents as well,such as aminoglycosides and fluoroquinolones, leaving a limited range of treatment options ${ }^{6}$. The aim of this study was to reveal the prevalence of antimicrobial resistance and the molecular bases of plasmid-mediated resistance among bacterial uropathogens in one of the major clinical settings in Cairo, Egypt.

\section{Materials and methods Specimen collection}

Starting October 2015 to May 2016, a total of 150 bacterial isolates were recovered from urine specimens of patients suffering signs and symptoms of UTIs at the outpatient clinics of El-Demerdash Hospital, Cairo, Egypt. All specimens were mid-stream urine and patients were instructed on how to collect specimens to avoid contamination. Patients included in the study were adults (ages ranging from 25 - 45 years), symptomatic, with pyuria (Pus cells $\geq 20 / H P F$ ), and the bacterial count in urine was $>10^{5} \mathrm{cfu} / \mathrm{ml}$. The study was approved by Faculty of Pharmacy, Ain Shams University Ethics Committee Nr. 212 and an informed consent was obtained from patients after explaining the study purpose.

\section{Identification of the recovered bacterial isolates}

Isolates were categorized based on their Gram reactions, followed by identification using standard methods. Identification to the species level was done for MDR isolates by using $\mathrm{API}^{\circledR} 20 \mathrm{E}$ identification kit and $\mathrm{API}^{\circledR}$ Staph identification kit (BioMérieux, France) for Gram-negative and Gram-positive isolates respectively.

\section{Antimicrobial susceptibility testing}

The Kirby-Bauer disk diffusion test was performed according to Clinical and Laboratory Standards Institute (CLSI) guidelines ${ }^{8,9}$ using commercially available antimicrobial disks (Oxoid, UK). The reference strains E. coli ATCC $^{\circledR} 25922$ and Stapbylococcus S. aureus ATCC ${ }^{\circledR} 25923$ were used for quality control. All MDR isolates were selected for further studying.

\section{Determination of minimum inhibitory concentra-} tion of multidrug-resistant isolates

Minimum inhibitory concentration (MIC) values of MDR isolates were determined by broth microdilution method according to CLSI guidelines ${ }^{9,10}$ using ceftriax- one, cefepime, meropenem, gentamicin, and ciprofloxacin. The reference strains E. coli ATCC ${ }^{\circledR} 25922$ and $S$. aureus ATCC ${ }^{\circledR} 25923$ were used for quality control.

\section{Extraction of DNA plasmids from multidrug-resis- tant isolates}

The extraction of DNA plasmids from MDR isolates was done using Zyppy $^{\mathrm{TM}}$ Plasmid Miniprep Kit (Zymo Research, USA) according to the manufacturer's instructions. The extracted DNA plasmids were analyzed via agarose gel electrophoresis ${ }^{11}$ and visualized by UV transilluminator.

\section{Amplification of plasmid-encoded resistance genes}

Amplification of antibiotic resistance genes was carried out by polymerase chain reaction (PCR) using the appropriate primers (Table 1); and the DNA plasmids of the MDR isolates as templates. Primers were manufactured by LGC Biosearch Technologies, USA. The amplified products were analyzed via agarose gel electrophoresis, and the expected DNA product size was determined by comparing to a $100 \mathrm{bp}$ DNA ladder (New England Biolabs, UK).

The antibiotic resistance genes amplified in this study included ESBL genes ( ${ }^{b l a} \mathrm{CTX}-\mathrm{M}$, ${ }^{b l a S H V}$, and $\left.{ }^{b l a} \mathrm{TEM}\right)$; the aac (6')-Ib gene conferring resistance to aminoglycosides, and its bifunctional variant aac( $\left.\sigma^{\prime}\right) I b-c r$ conferring resistance to both aminoglycosides and ciprofloxacin; low level resistance plasmid-mediated quinolone resistance (PMQR) genes ( $q n r A, q n r B, q n r S)$, and quinolone efflux pump genes (qepA, oq $\times A, o q \times B)$.

\section{Sequencing of selected PCR products}

Some selected PCR products of amplified genes were sent for sequencing at GATC, Germany using ABI 3730 $\mathrm{xl}$ DNA Sequencer. The alignment and assembly of the obtained forward and reverse sequence files into the final consensus was done using BioEdit v7.2.5 software $^{16}$.

\section{Transformation}

Plasmids extracted from the MDR isolates were used to transform competent E. coli $\mathrm{DH} 5 \alpha$ prepared according to the modified Hanahan method ${ }^{17}$ to test the phenotypic resistance of the transformants. Transformants were cultured on LB/ampicillin, LB/gentamicin, and LB/ciprofloxacin agar plates at concentrations of $100 \mu \mathrm{g} / \mathrm{ml}, 25$ $\mu \mathrm{g} / \mathrm{ml}$, and $50 \mu \mathrm{g} / \mathrm{ml}$, respectively. 


\section{Statistical analysis}

Categorical variables were analyzed using the Chi-square test to determine statistical significance. Statistical analysis including descriptive statistics, frequency tables, and cross-tabulations was performed using Statistical Package for the Social Sciences software IBM ${ }^{\circledR}$ SPSS $^{\circledR}$ version $20^{18}$. A value of $\mathrm{P}<0.05$ was considered statistically significant, and significance was two-sided.

\section{Results}

\section{Identification of the recovered bacterial isolates}

Of the 150 recovered isolates; 79 (52.7\%) were from female patients, and $71(47.3 \%)$ were from male patients. Gram-negative bacilli (GNB) represented $77.3 \%$ of the total isolates $(\mathrm{n}=116) ; 107$ of which $(92.2 \%)$ were identified as members of Enterobacteriaceae, 7 (6\%) were Pseudomonas spp., and $2(1.7 \%)$ were Acinetobacter spp. On the other hand, 34 isolates $(22.7 \%)$ were Gram-positive cocci (GPC); 23 of which $(67.6 \%)$ were coagulase-negative
Staphylococcus spp., 6 (17.6\%) were Staphylococcus aureus, and $5(14.7 \%)$ were Enterococcus spp.

\section{Antimicrobial susceptibility testing}

The antimicrobial susceptibility patterns of the recovered isolates are shown in Table 2. Out of 150 isolates; 65 (43.3\%) were MDR; 51 of which $(78.5 \%)$ were Gram-negative including E. coli (24/51; 47.1\%), Klebsiella (K.) pneumoniae $(15 / 51 ; 29.4 \%)$, K. terrigena (4/51; 7.8\%), Proteus mirabilis (5/51; 9.8\%), Acinetobacter (A.) baumannii $(2 / 51 ; 3.9 \%)$, and Pseudomonas $(P$.$) aeruginosa (1 / 51 ; 2 \%)$. Meanwhile; $14(21.5 \%)$ of the 65 MDR isolates were Gram-positive including $S$. aureus $(4 / 14 ; 28.6 \%)$, S. haemolyticus $(3 / 14 ; 21.4 \%), S$. xylosus $(3 / 14 ; 21.4 \%)$, S. epidermidis $(2 / 14 ; 14.3 \%)$, and $S$. lentus $(2 ; 14.3 \%)$. Results of the antimicrobial suscepibility of the recovered isolates are presented in table S1. The prevalence of antimicrobial resistance of the tested MDR Gram-negative and Gram-positive isolates to different anti-microbial agents is shown in Figures 1 and 2, respectively.

Table 1. Primers sequences, expected product sizes, and annealing temperatures $\left(T_{a}\right)$ of the tested genes

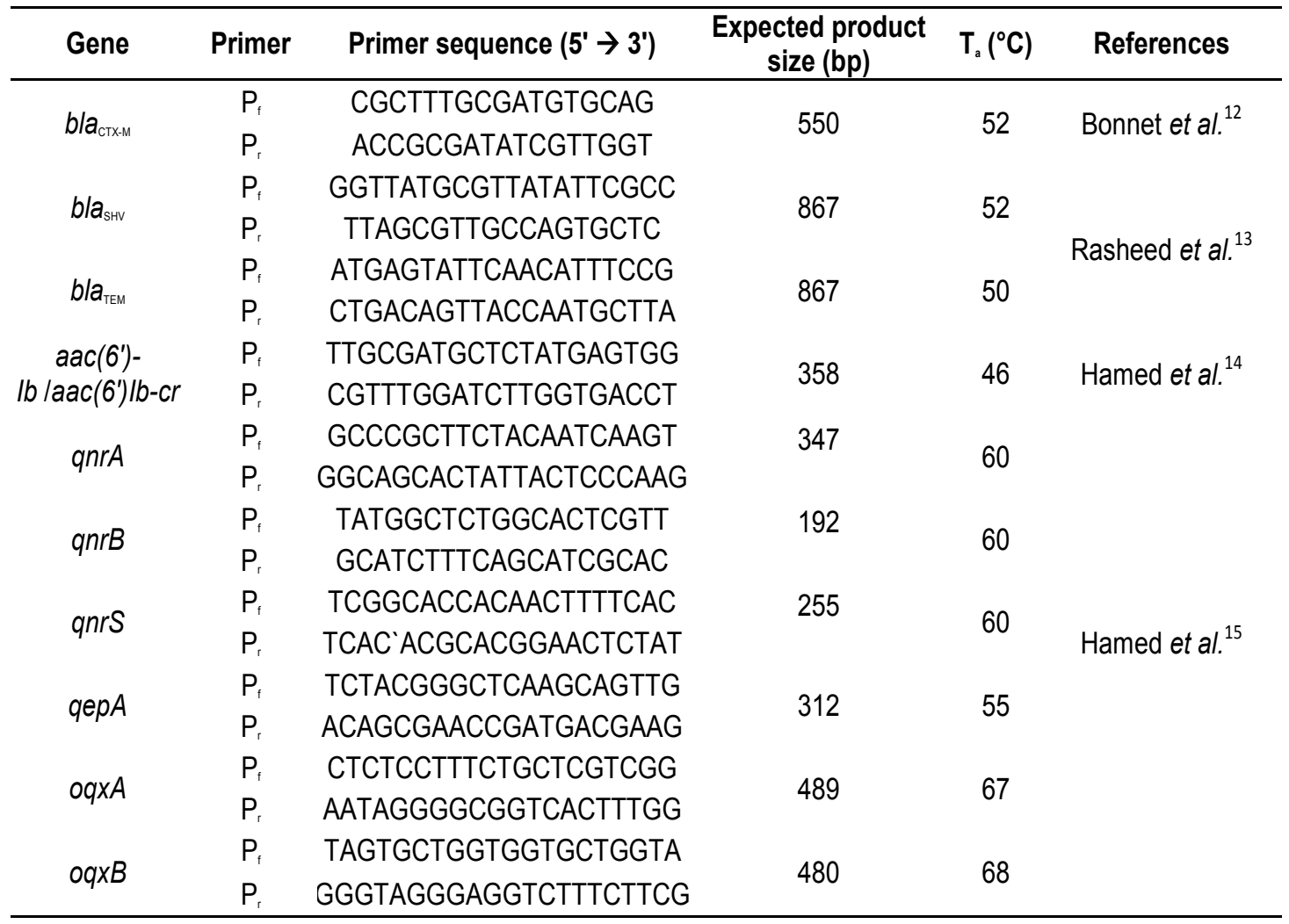

Notes: $b / a_{\text {стX-M }}, b / a_{\text {SHV }}$, and $b / a_{\text {тЕм }}$ genes code for ESBLs; aac $\left(6^{\prime}\right)-l b$ gene codes for aminoglycoside 6'-N-acetyltransferase type Ib; aac $\left(6^{\prime}\right)-l b$-crgene codes for aminoglycoside 6'-N-acetyltransferase type lb ciprofloxacin-resistant variant; qnrA, qnrB, and qnrS genes are PMQR determinants coding for quinolone resistance; qep $A$, oqxA, and oqxB genes code for plasmid-mediated quinolone efflux pump resistance.

Abbreviations: $T_{a}$, calculated annealing temperature; ESBLs, extended-spectrum beta-lactamases; PMQR, plasmidmediated quinolone resistance. 


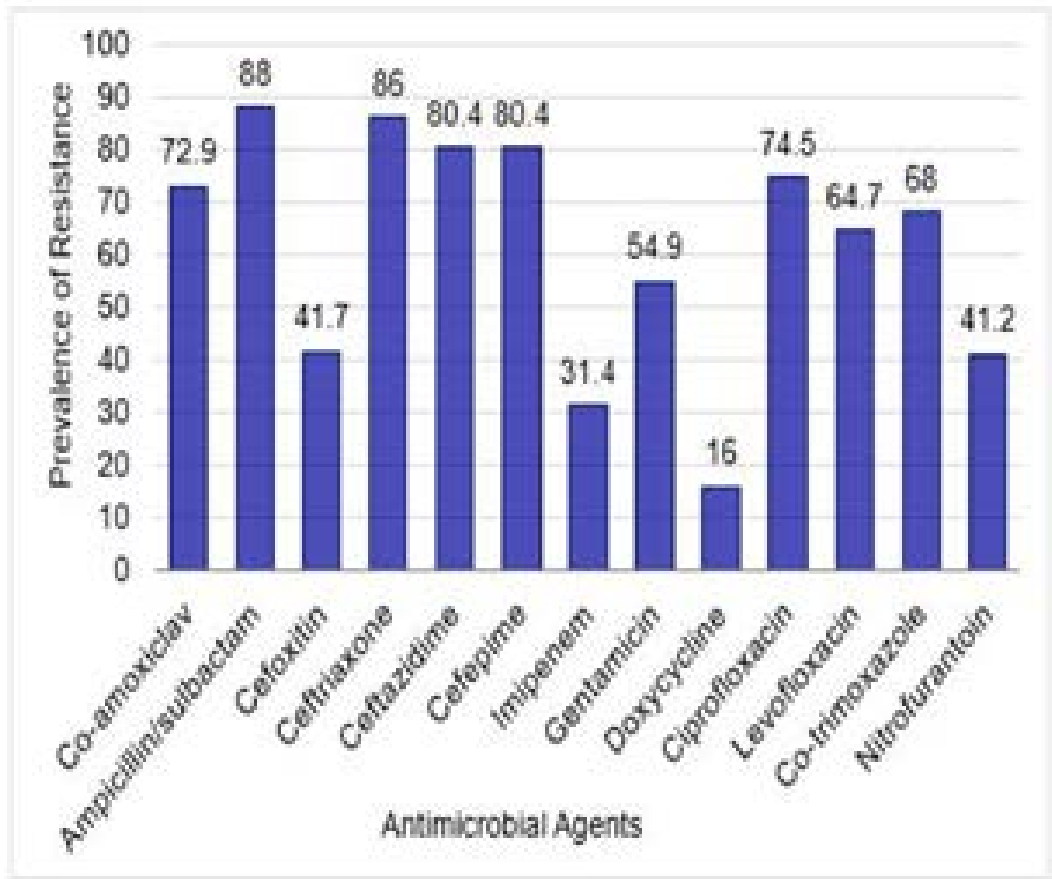

Figure 1. Prevalence of antimicrobial resistance of the 51 tested MDR GNB isolates to Different antimicrobial agents. Prevalence was expressed as percent of resistant isolates relative to total tested isolates for each antimicrobial agent

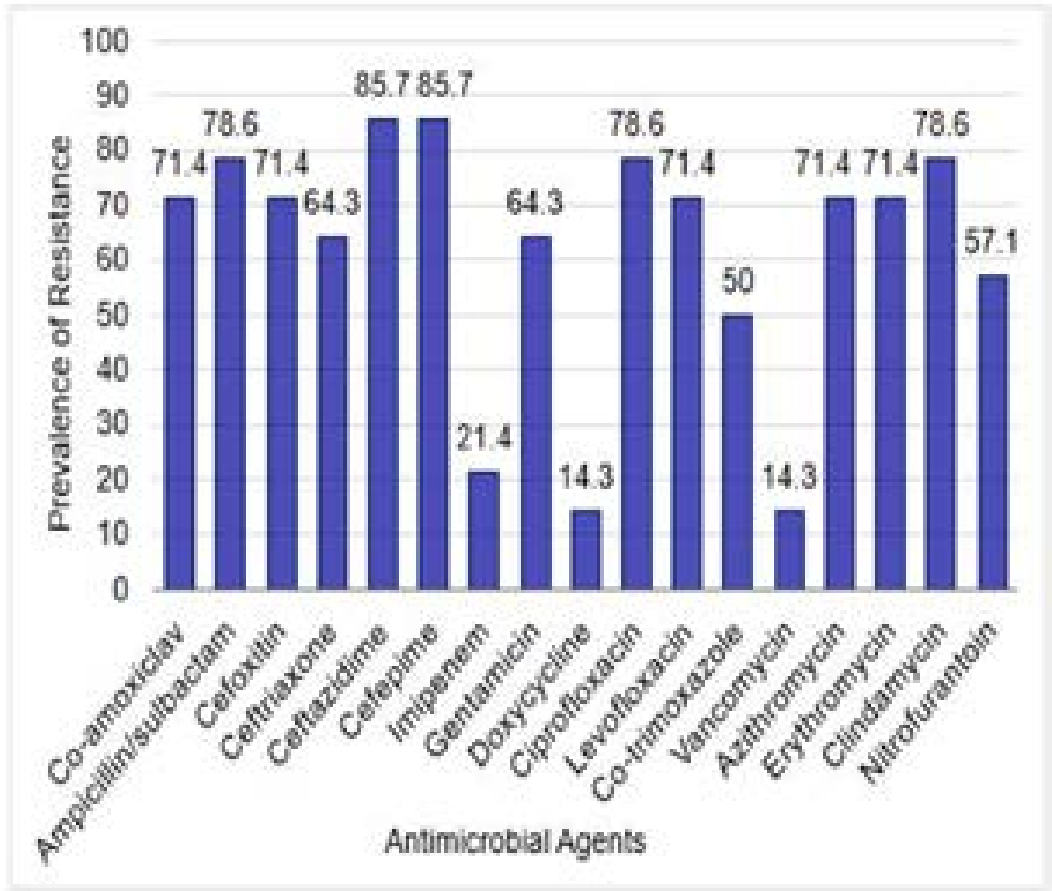

Figure 2. Prevalence of antimicrobial resistance of the 14 tested MDR GPC isolates to different anti-microbial agents. Prevalence was expressed as percent of resistant isolates relative to total tested isolates for each antimicrobial agent 
Minimum inhibitory concentrations of MDR iso- lates are shown in supplementary tables S2 and S3, relates

The obtained MIC results of MDR GNB and GPC isospectively.

Table 2. Antimicrobial susceptibility patterns of the recovered 150 isolates

\begin{tabular}{|c|c|c|c|c|c|c|}
\hline \multirow[t]{3}{*}{ Antibiotics } & \multicolumn{6}{|c|}{ Resistant isolates, $\mathrm{n}(\%)$} \\
\hline & $\begin{array}{l}\text { Enterobacteriaceae } \\
\qquad(\mathrm{n}=107)\end{array}$ & $\begin{array}{c}\text { Pseudomonas } \\
\text { spp. }(n=7)\end{array}$ & $\begin{array}{c}\text { Acinetobacter } \\
\text { spp. }(\mathrm{n}=2)\end{array}$ & $\begin{array}{l}\text { Staphylococcus } \\
\text { aureus }(n=6)\end{array}$ & $\begin{array}{c}\text { Coagulase } \\
\text {-negative } \\
\text { Staphyloc } \\
\text { occus spp. } \\
\quad(\mathrm{n}=23)\end{array}$ & $\begin{array}{c}\text { Enterococcus } \\
\text { spp. }(n=5)\end{array}$ \\
\hline & $\mathbf{R}$ & $\mathbf{R}$ & $\mathbf{R}$ & $\mathbf{R}$ & $\mathbf{R}$ & $\mathbf{R}$ \\
\hline Co-amoxiclav & $53(49.5)$ & nd & nd & $2(33.3)$ & $9(39.1)$ & nd \\
\hline $\begin{array}{l}\text { Ampicillin/ } \\
\text { sulbactam }\end{array}$ & $55(51.4)$ & nd & $2(100)$ & $3(50.0)$ & $9(39.1)$ & nd \\
\hline Cefoxitin & $24(22.4)$ & nd & nd & $3(50.0)$ & $10(43.5)$ & nd \\
\hline Ceftriaxone & $42(39.3)$ & nd & $1(50.0)$ & $1(16.7)$ & $8(34.8)$ & nd \\
\hline Ceftazidime & 44 (41.1) & $3(42.9)$ & $2(100)$ & $3(50.0)$ & $10(43.5)$ & nd \\
\hline Cefepime & $46(43.0)$ & $1(14.3)$ & $1(50.0)$ & $3(50.0)$ & $9(39.1)$ & nd \\
\hline Imipenem & $17(15.9)$ & $0(0.0)$ & $2(100)$ & $1(16.7)$ & $2(8.7)$ & nd \\
\hline Gentamicin & $26(24.3)$ & $1(14.3)$ & $2(100)$ & $1(16.7)$ & $8(34.8)$ & nd \\
\hline Doxycycline & $12(11.2)$ & nd & $0(0.0)$ & $1(16.7)$ & $1(4.3)$ & $0(0.0)$ \\
\hline Ciprofloxacin & $43(40.2)$ & $2(28.6)$ & $2(100)$ & $1(16.7)$ & $11(47.8)$ & $1(20.0)$ \\
\hline Levofloxacin & $35(32.7)$ & $2(28.6)$ & $1(50.0)$ & $2(33.3)$ & $8(34.8)$ & $1(20.0)$ \\
\hline Co-trimoxazole & $40(37.4)$ & nd & $2(100)$ & $2(33.3)$ & $6(26.1)$ & nd \\
\hline Vancomycin & nd & nd & nd & $1(16.7)$ & $1(4.3)$ & $1(20.0)$ \\
\hline Azithromycin & nd & nd & nd & $3(50.0)$ & $8(34.8)$ & nd \\
\hline Erythromycin & nd & nd & nd & $3(50.0)$ & $8(34.8)$ & $2(40.0)$ \\
\hline Clindamycin & nd & nd & nd & $3(50.0)$ & $9(39.1)$ & nd \\
\hline Nitrofurantoin & $40(37.4)$ & nd & nd & $6(100)$ & $11(47.8)$ & $0(0.0)$ \\
\hline
\end{tabular}

Abbreviations: $\mathrm{R}$, resistant; $\mathrm{nd}$, not determined (due to lack of interpretation data in CLSI guidelines).

Table 3. Percentage of plasmid-mediated antimicrobial resistance genotypes of MDR isolates and statistically significant associations

\begin{tabular}{|c|c|c|c|c|}
\hline $\begin{array}{l}\text { MDR isolates } \\
\text { harboring } \\
\text { plasmids }\end{array}$ & Genotypes & $\begin{array}{l}\text { No. of } \\
\text { isolates }(\% *)\end{array}$ & $\begin{array}{l}\text { Significant } \\
\text { associations }\end{array}$ & $\begin{array}{l}\text { Pearson chi- } \\
\text { square }\end{array}$ \\
\hline \multirow[t]{22}{*}{ Positive $(n=39)$} & $b / a_{\text {ст } \mathrm{N}} / \mathrm{b} / a_{\text {тЕ }} / a a c\left(6^{\prime}\right)-I b / q n r S$ & $5(7.7 \%)$ & ${ }^{\mathrm{a}} \mathrm{Co}-$ amoxiclav/bla $\mathrm{S}_{\mathrm{SHV}}$ & 0.026 \\
\hline & $b / a_{\text {Стх- }} / b / a_{\text {тЕN }} / a a c\left(6^{\prime}\right)-l b / q n r S / o q x B$ & $4(6.2 \%)$ & ${ }^{\mathrm{a}}$ cefoxitin/b/a $\mathrm{SHV}$ & 0.002 \\
\hline & 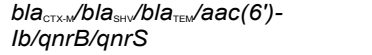 & $4(6.2 \%)$ & aimipenem $/ b / a_{\mathrm{sHv}}$ & 0.012 \\
\hline & $b / a_{\text {стхм }} /$ bla $a_{\text {SнV }} / a a c\left(6^{\prime}\right)-I b / q n r B / q n r S$ & $3(4.6 \%)$ & ${ }^{\mathrm{a}}$ meropenem $/ b / a_{\mathrm{sHv}}$ & 0.01 \\
\hline & $b / a_{\mathrm{CTX}-\mathrm{M}} / \mathrm{b} / a_{\mathrm{SH}} / \mathrm{b} / a_{\mathrm{TEM}} / \mathrm{aac}\left(6^{\prime}\right)-I b / q n r S$ & $2(3.1 \%)$ & & \\
\hline & $\begin{array}{l}\text { bla } a_{\text {стхм }} / \text { b/a } a_{\text {тем }} / a a c\left(6^{\prime}\right)- \\
\text { Ib/qnrS/oqxA/oqxB }\end{array}$ & $2(3.1 \%)$ & ${ }^{\circ} b / a_{\text {стхN }} / a a c\left(6^{\prime}\right)-l b$ & 0.001 \\
\hline & $b / a_{\text {стхي }} / a a c\left(6^{\prime}\right)-l b / q n r B / q n r S$ & $2(3.1 \%)$ & ${ }^{b} b / a_{\mathrm{sHV}} / q n r B$ & 0.018 \\
\hline & bla $a_{\text {стхк }} / b / a_{\text {тЕм }} / a a c\left(6^{\prime}\right)-I b / q n r B / q n r S$ & $2(3.1 \%)$ & ${ }^{\circ} \mathrm{bla}{ }_{\mathrm{SHV}} / \mathrm{qnrS}$ & 0.031 \\
\hline & $b / a_{\text {СтX-M }} / b / a_{\text {SHV }} / b / a_{\text {TЕM }} / a a c\left(6^{\prime}\right)-l b / q n r B$ & $2(3.1 \%)$ & ${ }^{b} b / a_{\mathrm{SHV}} / o q \times B$ & 0.035 \\
\hline & $b l a_{\mathrm{SH}} / b / a_{\mathrm{TEM}}$ & $1(1.5 \%)$ & ${ }^{b} \mathrm{~b} / a_{\mathrm{TEN}} / q n r B$ & 0.047 \\
\hline & $\begin{array}{l}\text { bla } a_{\text {стх- } /} / \text { bla } \\
\text { Ib/qnrB/aac }\left(6^{\prime}\right)- \\
\text { (bnrS/oqxA/oqxB }\end{array}$ & $1(1.5 \%)$ & ${ }^{b} q n r B / o q \times B$ & 0.01 \\
\hline & $\begin{array}{l}\text { bla } a_{\text {стхN }} / \text { bla } a_{\text {тЕм }} / \text { aac }\left(6^{\prime}\right)- \\
\text { Ib/qnrA/qnrS/oqxB }\end{array}$ & $1(1.5 \%)$ & & \\
\hline & 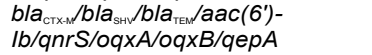 & $1(1.5 \%)$ & & \\
\hline & $b / a_{\text {тЕм }} / q n r B / q n r S$ & $1(1.5 \%)$ & & \\
\hline & 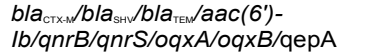 & $1(1.5 \%)$ & & \\
\hline & $b / a_{\mathrm{SH}} / \mathrm{b} / a_{\mathrm{TEN}} / a a c\left(6^{\prime}\right)-l b / q n r B / q n r S$ & $1(1.5 \%)$ & & \\
\hline & $b^{b} a_{\text {стхي }} / q n r S / o q \times A / o q x B$ & $1(1.5 \%)$ & & \\
\hline & $\begin{array}{l}\text { bla }_{\text {стх-м }} / \text { bla }_{\text {тЕN }} / \text { aac }\left(6^{\prime}\right)- \\
\text { Ib/qnrA/qnrS/oqxB/qepA }\end{array}$ & $1(1.5 \%)$ & & \\
\hline & 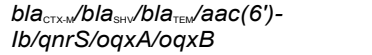 & $1(1.5 \%)$ & & \\
\hline & $b / a_{\mathrm{CTX} \times \mathrm{M}} / \mathrm{b} / a_{\mathrm{TEM}} / \mathrm{aac}\left(6^{\prime}\right)-I b / q n r A / q n r S$ & $1(1.5 \%)$ & & \\
\hline & 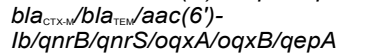 & $1(1.5 \%)$ & & \\
\hline & $b / a_{\mathrm{TEN}} / a a c\left(6^{\prime}\right)-l b / q n r S / o q \times B$ & $1(1.5 \%)$ & & \\
\hline Negative $(n=26)$ & - & $26(40 \%)$ & & \\
\hline
\end{tabular}

Notes: genotypes, plasmid-mediated antimicrobial resistance. *Percentages were calculated with reference to the number of MDR isolates $(n=65)$. aSignificant association between antibiotic resistance and PCR detection of the respective gene on plasmids. 'Significant co-existence of resistance genes on plasmids of the same isolate.

Abbreviations: MDR, multidrug-resistant; PCR, polymerase chain reaction. 


\section{Extraction of DNA Plasmids from MDR isolates}

DNA plasmids were extracted from $39(60 \%)$ of the 65 MDR isolates. The extracted plasmids were analyzed via agarose gel electrophoresis, and the band sizes were compared to a $1 \mathrm{~kb}$ DNA ladder (New England Biolabs, UK).

\section{Amplification of some plasmid-encoded resistance genes}

Results of PCR amplification of the ESBL genes $\left({ }^{b l a} \mathrm{C}\right.$ TX-M, blaSHV, and bla TEM); the aac(6')-Ib gene, plasmid-mediated quinolone resistance (PMQR) genes (qnrA, qnrB, $q n r S)$, and quinolone efflux pump genes (qep $A, \circ q \times A$, $\circ q \times B)$ are depicted in figures S1, S2 and S3. The prevalence of amplified antibiotic resistance genes among MDR bacterial uropathogens is shown in Figure 3.

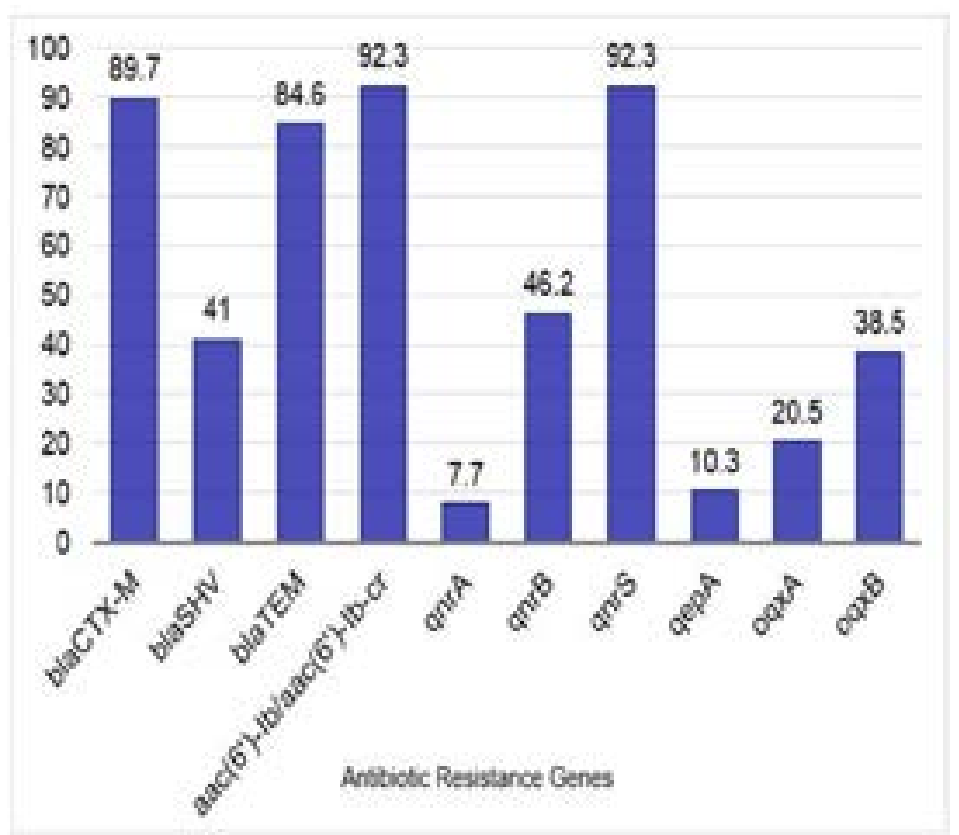

Figure 3. Prevalence of some selected antibiotic resistance genes among MDR bacterial uropathogens. Prevalence was expressed as percent of isolates carrying the tested genes relative to total tested isolates $(n=39)$

\section{Genotypes of MDR isolates}

Among the 65 MDR isolates; 22 different genotypes were observed based on the PCR detection of antimicrobial resistance genes on the extracted DNA plasmids of the MDR isolates, as shown in Table 3.

\section{Transformation}

The results of transformation along with PCR amplification for the tested isolates are shown in Table S4. In case of plasmids harboring ESBL coding genes ( $\mathrm{n}=39$ ), successful transformation and gene expression was achieved with plasmids extracted from 28 isolates $(71.8 \%)$ harboring such plasmids; demonstrated by the ability of transformants to grow on $\mathrm{LB} /$ ampicillin agar plates. Out of 36 MDR isolates that carried the aminoglycoside resistance gene $a a c\left(\sigma^{\prime}\right)-I b / a a c\left(6^{\prime}\right)-I b-c r$, the plasmids extracted from 15 isolates $(41.7 \%)$ were successfully transformed and resistance genes were expressed; which was demonstrated by the ability of transformants to grow on LB/ gentamicin agar plates. Isolates that carried any of the plasmid-mediated quinolone resistance (PMQR) genes (aac(6')-Ib-cr, qnrA, qnrB, qnrS, qepA, oqxA, and $о q \times B)$ were found to be 38 out of the 39 tested MDR isolates (97.4\%); plasmids extracted from 10 of which (26.3\%) were successfully transformed and resistance genes were expressed; demonstrated by the ability of transformants to grow on $\mathrm{LB} /$ ciprofloxacin agar plates.

\section{Statistical analysis}

Statistical analysis has shown that there is significant association between antimicrobial resistance and PCR detection of the respective genes on DNA plasmids. There is also significant co-existence of PCR-detected antibiotic resistance genes on DNA plasmids of the same isolate $(\mathrm{P}$ value $<0.05)$. The statistical association and respective $P$ values are shown in Table 3.

\section{Discussion}

As reported, UTIs are becoming more difficult to treat due to the emergence and prevalence of a wide range 
of antibiotic resistance mechanisms ${ }^{3}$. Accordingly, in this study we assessed both the phenotypic and genotypic bases of antimicrobial resistance of some MDR uropathogens against the most common antimicrobial agents used in treatment of UTIs.

The antimicrobial susceptibility of the GPC collected in this study $(n=34)$ showed that the lowest resistance was observed to doxycycline, vancomycin, and imipenem $(5.9 \%, 8.8 \%, 10.3 \%)$. On the other hand, the highest resistance was observed to nitrofurantoin (50.0\%); cefoxitin, ceftazidime ( $44.8 \%$ each); ampicillin/sulbactam and cefepime (41.4\% each). The antimicrobial susceptibility of the GNB ( $n=116)$ showed that the lowest resistance was observed to doxycycline $(11.0 \%)$ and imipenem (16.4\%). The highest resistance was observed to ampicillin/sulbactam (52.3\%); co-amoxiclav (49.5\%); ceftazidime $(42.2 \%)$; cefepime $(41.4 \%)$; and ciprofloxacin $(40.5 \%)$. These results limit the use of nitrofurans, cephalosporins, $\beta$-lactam/ $\beta$-lactamase inhibitors, and fluoroquinolones as empirical treatment of UTIs, while tetracyclines and carbapenems still retain their efficacy in treating UTIs based on in vitro data. Some other studies deduced that imipenem showed highest efficacy and may be the drug of choice for empirical therapy of UTIs based on the in vitro data ${ }^{19-21}$.

In this study, PCR amplification was used to detect some plasmid-mediated antimicrobial resistance genes associated with the $39 \mathrm{MDR}$ isolates harboring plasmids. The ESBLs genes were detected in all $39(100 \%)$ isolates with ${ }^{b l a}$ CTX-M gene showing highest prevalence (89.7\%), followed by blaTEM $(84.6 \%)$ then blasHV (41\%). Our findings agreed with the study conducted by Goudarzi et al. in 2015 which also revealed a dominant presence of ${ }^{b l a} \mathrm{C}$ TX-M (74.9\%), followed by bla TEM (70\%), then blasHV $(59.9 \%)^{22}$. Of the $39 \mathrm{MDR}$ isolates harboring plasmids, $36(92.3 \%)$ carried the ac6'-Ib/aac-6'-Ib-cr gene conferring resistance to aminoglycosides and ciprofloxacin, 11 of which $(30.6 \%)$ carried the three ESBLs genes together, and $23(63.9 \%)$ carried two of the ESBLs genes. A study conducted by Paterson et al. revealed that ESBL-producing $K$. pneumoniae isolates that were ciprofloxacin-resistant possessed multiple $\beta$-lactamases ${ }^{23}$, to which our results are in accordance. Our results also showed that there is a significant association between the presence of ${ }^{b l a}$ CTX-M gene and aac6'-Ib/aac-6'-Ib-cr gene in the same isolate $(\mathrm{P}=0.001)$. Accordingly, isolates that produce ES-
BLs also carry resistance genes to aminoglycosides and fluoroquinolones, thus reducing treatment options. This cross-resistance is more prominent in urinary isolates ${ }^{3}$. Therefore, carbapenems, which are less prone to hydrolysis by such enzymes, have become the preferred therapy for infections with ESBL-producing pathogens ${ }^{24-27}$.

The most prevalent $q n r$ gene in our study was $q n r S$ gene $(36 / 39 ; 92.3 \%)$, followed by $q n r B(18 / 39 ; 46.2 \%)$, and qnrA $(3 / 39 ; 7.7 \%)$. This prevalence pattern is in accordance to that obtained in a study conducted by several recent studies ${ }^{28-30}$. The quinolone efflux pump resistance genes were detected in $15(38.5 \%)$ out of the $39 \mathrm{MDR}$ isolates and their prevalence was highest for $o q \times B(15 / 39$; $38.5 \%)$, followed by oq $\times A(8 / 39 ; 20.5 \%)$, and qep $A(4 / 39$; $10.3 \%$ ). It should be noted that the acquisition of PMQR genes alone results in low levels of resistance to fluoroquinolones, and does not cause MICs to exceed the breakpoints of these agents ${ }^{31}$, but rather facilitates the selection of mutants of higher-level resistance ${ }^{32}$. This was evident in our study by the lack of statistically significant association between the presence of PMQR genes and resistance to fluoroquinolones, which means the presence of PMQR genes alone, did not confer resistance to fluoroquinolones.

\section{Conclusion}

High levels of resistance to antimicrobials commonly used for treatment of UTIs was detected among MDR uropathogens. The current efficacy of nitrofurans, $\beta$-lactam/ $\beta$-lactamase inhibitor, cephalosporins, aminoglycosides, and fluoroquinolones has become questionable. Carbapenems, tetracyclines, and vancomycin have yet to retain their efficacy in treatment of UTIsbased on in vitro data. No significant correlation was observed between the presence of PMQR genes and fluoroquinolone resistance, indicating that PMQR genes alone do not grant phenotypic resistance to fluoroquinolones, however the resistance may have been due to co-existence of ESBL and/or aac6'-Ib/aac-6'-Ib-cr genes in the same isolate or even on the same plasmids.

\section{Acknowledgements}

The authors are grateful to the Microbiology and Immunology department, Faculty of pharmacy, Ain Shams University for providing the laboratory facilities for this work. The authors would also like to acknowledge the Microbiology Laboratory at El-Demerdash Hospital, Ain Shams University, for providing the clinical specimens 


\section{Conflict of Interest Disclosure}

The authors declare that they have no conflict of interests

\section{References}

1. Flores-Mireles AL, Walker JN, Caparon M, Hultgren SJ. Urinary tract infections: epidemiology, mechanisms of infection and treatment options. Nat Rev Microbiol. 2015 May;13(5):269-284.

2. Kahlmeter G. An international survey of the antimicrobial susceptibility of pathogens from uncomplicated urinary tract infections: the ECO.SENS Project. J Antimicrob Chemother. 2003 Jan 1;51(1):69-76.

3. Gupta K, Bhadelia N. Management of Urinary Tract Infections From Multidrug-Resistant Organisms. Infect Dis Clin North Am. 2014 Mar;28(1):49-59.

4. Farrell DJ, Morrissey I, De Rubeis D, Robbins M, Felmingham D. A UK Multicentre Study of the Antimicrobial Susceptibility of Bacterial Pathogens Causing Urinary Tract Infection. J Infect. 2003 Feb;46(2):94-100.

5. Magiorakos A-P, Srinivasan A, Carey RB, Carmeli Y, Falagas ME, Giske CG, et al. Multidrug-resistant, extensively drug-resistant and pandrug-resistant bacteria: an international expert proposal for interim standard definitions for acquired resistance. Clin Microbiol Infect. 2012 Mar;18(3):268-281.

6. Mukherjee M. Multidrug-Resistance and Extended Spectrum Beta-Lactamase Production in Uropathogenic E. Coli which were Isolated from Hospitalized Patients in Kolkata, India. J Clin Diagn Res. 2013;7(3):449-453.

7. Zowawi HM, Harris PNA, Roberts MJ, Tambyah PA, Schembri MA, Pezzani MD, et al. The emerging threat of multidrug-resistant Gram-negative bacteria in urology. Nat Rev Urol. 2015 Sep 1;12(10):570-584.

8. Clinical and Laboratory Standards Institute. Performance standards for antimicrobial disk susceptibility tests; approved standard - twelfth edition. CLSI document M02-A12. Wayne, PA: CLSI [Internet]. 2015; Available from: http://www.facm.ucl.ac.be/intranet/CLSI/ CLSI-2015-M02-A12-original.pdf

9. Clinical and Laboratory Standards Institute. Performance standards for antimicrobial susceptibility testing 26th ed. CLSI supplement M100S. Wayne, PA: CLSI [Internet]. 2016; Available from: http://www.facm.ucl. ac.be/intranet/CLSI/CLSI-2016-M100-S26.pdf

10. Clinical and Laboratory Standards Institute. Methods for dilution antimicrobial susceptibility tests for bacteria that grow aerobically; approved standard - tenth edition.
CLSI document M07-A10. Wayne, PA: CLSI [Internet]. 2015; Available from: http://www.facm.ucl.ac.be/intranet/CLSI/CLSI-2015-M07-A10-original.pdf

11. Sambrook J, Russel DW. Molecular cloning: a laboratory manual. 4th ed. Cold Spring Harbor, N.Y: Cold Spring Harbor Laboratory Press; 2012.

12. Bonnet R, Dutour C, Sampaio JL, Chanal C, Sirot D, Labia R, et al. Novel cefotaximase (CTX-M-16) with increased catalytic efficiency due to substitution Asp-240-> Gly. Antimicrob Agents Chemother. 2001 Aug;45(8):22692275.

13. Rasheed JK, Jay C, Metchock B, Berkowitz F, Weigel L, Crellin J, et al. Evolution of extended-spectrum beta-lactam resistance (SHV-8) in a strain of Escherichia coli during multiple episodes of bacteremia. Antimicrob Agents Chemother. 1997 Mar;41(3):647-653.

14. Hamed SM, Aboshanab K, Elkhatib WF, Ashour MS. Aminoglycoside Resistance Patterns of Certain Gram Negative Uropathogens Recovered from Hospitalized Egyptian Patients. 2013;3(4):678-691.

15. Hamed SM, Aboshanab KMA, El-Mahallawy HA, Helmy MM, Ashour MS, Elkhatib WF. Plasmid-Mediated Quinolone Resistance in Gram-Negative Pathogens Isolated from Cancer Patients in Egypt. Microb Drug Resist. 2018 Mar 13;0(0).

16. Hall TA. BioEdit: a user-friendly biological sequence alignment editor and analysis program for Windows 95/98/NT. Nucleic Acids Symp Ser. 1999;41(2):95-98.

17. Hanahan D. Studies on transformation of Escherichia coli with plasmids. J Mol Biol. 1983;166(4):557-580.

18. IBM. SPSS Statistics for Windows. Version 20.0. Armonk, NY: IBM; 2011.

19. Muvunyi CM, Masaisa F, Bayingana C, Mutesa L, Musemakweri A, Muhirwa G, et al. Decreased Susceptibility to Commonly Used Antimicrobial Agents in Bacterial Pathogens Isolated from Urinary Tract Infections in Rwanda: Need for New Antimicrobial Guidelines. Am J Trop Med Hyg. 2011 Jun 1;84(6):923-928.

20. Akram M, Shahid M, Khan AU. Etiology and antibiotic resistance patterns of community-acquired urinary tract infections in J N M C Hospital Aligarh, India. Ann Clin Microbiol Antimicrob. 2007;6(1):4-10.

21. Raeispour M, Reza R. Antibiotic resistance, virulence factors and genotyping of Uropathogenic Escherichia coli strains. Antimicrob Resist Infect Control. 2018 Oct 3;7(1):118-126.

22. Goudarzi M, Azad M, Seyedjavadi SS. Prevalence of 
Plasmid-Mediated Quinolone Resistance Determinants and OqxAB Efflux Pumps among Extended-Spectrum $\beta$-Lactamase Producing Klebsiella pneumoniae Isolated from Patients with Nosocomial Urinary Tract Infection in Tehran, Iran. Scientifica. 2015;2015:1-7 PubMed .

23. Paterson DL, Mulazimoglu L, Casellas JM, Ko W-C, Goossens H, Von Gottberg A, et al. Epidemiology of Ciprofloxacin Resistance and Its Relationship to Extended-Spectrum $\beta$-Lactamase Production in Klebsiella pneumoniae Isolates Causing Bacteremia. Clin Infect Dis. 2000;30:473-478 PubMed .

24. Lautenbach E, Strom BL, Bilker WB, Patel JB, Edelstein PH, Fishman NO. Epidemiological Investigation of Fluoroquinolone Resistance in Infections Due to Extended-Spectrum $\beta$-Lactamase-Producing Escherichia coli and Klebsiella pneumoniae. Clin Infect Dis. 2001;33:12881294 PubMed .

25. MacVane SH, Tuttle LO, Nicolau DP. Impact of extended-spectrum $\beta$-lactamase-producing organisms on clinical and economic outcomes in patients with urinary tract infection: Outcomes of ESBL-EK UTI. J Hosp Med. 2014 Apr;9(4):232-238.

26. Schwaber MJ, Navon-Venezia S, Schwartz D, Carmeli Y. High Levels of Antimicrobial Coresistance among Extended-Spectrum- -Lactamase-Producing Enterobacteriaceae. Antimicrob Agents Chemother. 2005 May 1;49(5):2137-2139.

27. Hoban DJ, Nicolle LE, Hawser S, Bouchillon S,
Badal R. Antimicrobial susceptibility of global inpatient urinary tract isolates of Escherichia coli: results from the Study for Monitoring Antimicrobial Resistance Trends (SMART) program: 2009-2010. Diagn Microbiol Infect Dis. 2011 Aug;70(4):507-511.

28. Abbasi H, Ranjbar R. The prevalence of quinolone resistance genes of $\mathrm{A}, \mathrm{B}, \mathrm{S}$ in Escherichia coli strains isolated from three major hospitals in Tehran, Iran. Cent European J Urol. 2018;71(1):129 PubMed -133.

29. Ranjbar R, Tolon SS, Sami M, Golmohammadi R. Detection of Plasmid-Mediated qnr Genes Among the Clinical Quinolone-Resistant Escherichia coli Strains Isolated in Tehran, Iran. Open Microbiol J. 2018;12:248-253 PubMed .

30. Ranjbar R, Farahani O. The Prevalence of Plasmid-mediated Quinolone Resistance Genes in Escherichia coli Isolated from Hospital Wastewater Sources in Tehran, Iran. Iran J Public Health. 2017 Sep;46(9):1285-1291

31. Sato T, Yokota S, Uchida I, Okubo T, Ishihara K, Fujii N, et al. A Fluoroquinolone- Resistant Escherichia coli Clinical Isolate without Quinolone Resistance-Determining Region Mutations Found in Japan. Antimicrob Agents Chemother. 2011 Aug;55(8):3964-3965.

32. Xue G, Li J, Feng Y, Xu W, Li S, Yan C, et al. High Prevalence of Plasmid-Mediated Quinolone Resistance Determinants in Escherichia coli and Klebsiella pneumoniae Isolates from Pediatric Patients in China. Microb Drug Resist. 2017 Jan;23(1):107-114. 